\title{
VÝSTAVNÍ POLITIKA ODDĚLENÍ NOVODOBÝCH ČESKÝCH DĚJIN V LETECH 1973-1989'
}

\author{
Marek Junek
}

Exhibition policy of the Department of modern Czech history over the years 1973-1989

\begin{abstract}
The National Museum started increasingly to engage in exhibitions devoted to twentieth-century history, subsequent to the foundation of the Department of modern Czech history. Until then, it had left this subject area to the Party museums in Prague. Individual exhibitions were particularly devoted to anniversaries marking the emergence of KSČ (the Communist Party of Czechoslovakia), the Slovak national uprising, the end of the War, the year 1948 and building socialism. They varied in standard, and were based on ideas from the document "Lessons from the evolution of the crisis in the party and society after the 13 th KSČ congress of 1970 " and on the associated museological methodologies. However, at the same time they were conceived in a manner that reflected the acquisition conception of the Department, and sought to present political as well as cultural, economic and social topics. They also endeavoured to portray everyday life. All these exhibitions may thus be considered a preparatory stage that culminated in the permanent exhibition on the history of the twentieth century.
\end{abstract}

Keywords: National Museum, exhibition policy, normalisation, interpretation of history, history of the twentieth century

Contact: Mgr. Marek Junek, Ph.D., Historické muzeum Národního muzea, Václavské náměstí 68, 11000 Praha; marek.junek@nm.cz

Národní muzeum v období let 1948-1989 uspořádalo celou řadu výstav, které se věnovaly historickým tématům. Až do počátku 70. let 20. století převažovaly výstavy s náměty z dějin před rokem 1914. Bylo to dáno zejména tím, že Národní muzeum se v rámci historické sbírky nezaměřovalo na dokumentaci 20. století, ta byla realizována nesystematicky a doplňkově. Existovaly ale výjimky dané strukturou Národního muzea. Proto se v období 50. a 60. let moderním dějinám věnují výstavy sportovní, divadelní nebo výstavy pořádané Archivem Národního muzea. Situace se změnila po vzniku oddělení novodobých českých dějin a poté, co bylo rozhodnuto, že se jeho funkce změní z dokumentační na sbírkovou. V další části se proto budeme věnovat období let 1973-1989, kdy výstavy věnované dějinám 20. století byly realizovány tímto oddělením. Bylo vybráno 7 výstav, které vznikly k výročím, anebo reflektovaly delší časový úsek dějin 20. století. Většinu výstav je pak možné vnímat jako prrípravnou fázi na realizaci stálé expozice, která se začala připravovat ve 2 . polovině 70 . let.

V období 50. a 60. let minulého století se výstavám zaměřeným na dějiny 20 . století věnovala zejména stranická muzea (Muzeum Klementa Gottwalda, Muzeum V. I. Lenina a Muzea dělnického hnutí v Českých Budějovicích a v Brně), která se stala důležitým komunikačním nástrojem státního aparátu v totalitní společnosti. Tato muzea měla svůj původ ve velkých mobilizačních výstavách (Dějiny KSČ, Výstava dějin revolučních bojů, výstavka darů Klementa Gottwalda), které byly prímo organizovány Ústavem dějin KSČ. ${ }^{2}$ Zbývající muzea v tomto úkolu hrála spíše druhořadou roli.

Muzea v období po roce 1948 měla nejenom dokumentovat dějiny, ale také je měla náležitě interpretovat v duchu komunistické ideologie a trrídního pojetí lidských dějin. Společenská role muzeí rovněž spočívala ve správné interpretaci důležitých soudobých událostí a některé výstavy (např. o volbách, o vývoji na Blízkém východě) měly ukazovat správný občanský př́istup k aktuálním problémům. ${ }^{3}$

Výstavní činnost Národního muzea v období 50. a 60. let se událostem moderních dějin věnovala jen okrajově. Situace se změnila v souvislosti se zrrízením oddělení novějších českých dějin (1961-1967) a zejména po jeho obnovení v letech sedmdesátých. ${ }^{4}$

Hlavním impulsem pro jeho zrrízení se stala snaha nově vykládat dějiny 20 . století v souvislosti s ideovým programem definovaným v Poučení z krizového vývoje ve straně a společnosti po XIII. sjezdu KSČ z roku 1970. Jejich

\footnotetext{
1 Předložená práce vznikla za finanční podpory Ministerstva kultury v rámci institucionálního financování dlouhodobého koncepčního rozvoje výzkumné organizace Národní muzeum (DKRVO 2019-2023/15.II.c, 00023272).

2 Vítězslav SOMMER, Angažované déjepisectví. Stranická historiografie mezi stalinismem a reformačním komunismem (1950-1970), Praha 2011, S. $72-98$.

3 Ondřej TÁBORSKÝ - Marek JUNEK, Scénář výstavy Rudá muzea, Národní muzeum, Praha 2011.

${ }^{4}$ Blíže viz Stanislav SLAVÍK, Oddělení novodobých českých dějin, in: Průvodce. Historické muzeum, Národní muzeum, Praha 1999, s. 43. Karel SKLENÁř, Obraz vlasti. Př́běh Národního muzea, Praha 2001, s. 382.
} 
implementací do muzejního života se staly Zásady rozvoje českého muzejnictví z roku 1973, které odrážely politicko-společenské poměry počátku normalizace. V „Poučení“ se zejména politicky správně interpretovalo období pražského jara jako kontrarevoluce a invaze vojsk Varšavské smlouvy se definovala jako bratrská pomoc. Současně ale byl nastaven základní narativ výkladu dějin 20 . století, který měl jasně ukázat vedoucí roli KSČ ve společnosti a pozitivně definovat Sovětský svaz jako vzor. Proto byly novodobé dějiny Čechů a Slováků charakterizovány dvěma základními proudy: ,, bojem za sociální osvobození pracujících a zápasem za existenci našich národů a jejich svobodu. Jejich tř́dní a národni, vnitřni a mezinárodni aspekty se navzájem prolinaly a ovlivňovaly. "5 V podobném duchu byla realizována většina výstav odrážejících politické dění ve 20 . století.

„Poučení“ následně rozvinuly Zásady rozvoje českého muzejnictví, které včlenily muzea a galerie do struktury tehdejší společnosti. „Muzea a galerie jako ideově politic$k y$, naukově $i$ výchovně působicí instituce jsou významným nástrojem státní kulturní politiky. Svými specifickými prostredky působí na mládež i pracujicí, seznamují je s výsledky lidské práce, s př́rodou, vývojem uméní a techniky a s kulturnim odkazem minulosti, vzdělávají je, vychovávají politicky, naukové i esteticky $v$ duchu socialistického vlastenectví, proletářského internacionalismu i mezinárodní solidarity v třídním pojetí, vytvářejí uvědomělý vztah k národům SSSR i ke všem zemím socialistického společenství. "6

Důvodová zpráva uvedla, proč byly vůbec vydány. Zásady rozvoje českého muzejnictví (dále jen „Zásady“) reagovaly na závěry XIV. sjezdu KSČ a vyrovnávaly se s činností muzeí ve 2 . polovině 60 . let (zejména se snahou vytvořit na straně nezávislý Svaz pracovníků muzeí) v podobě konsolidace muzejní sítě a očisty od ,pravicových“ živlů. ,, $V m i$ nulém období se nám nepodařilo využit všech možností tak, jak to společenské potreby vyžadují. To vyvolává nutnost vytváret plánovitě předpoklady pro optimální využití muzeí a galerii jako účinných nástrojů státní kulturní politiky pro rozvoj socialistické společnosti, kultury a výchovy. "7 Smyslem „Zásad“" pak bylo nově definovat činnost a vytvořit z muzeí centra, která budou výrazně obohacovat kulturní život společnost a zejména vychovávat mládež. ${ }^{8} \mathrm{Z}$ hlediska výstavní politiky byly „Zásady“ postaveny na následujících principech: „,...muzea a galerie jsou kulturní zařizení, která svými specifickými prostředky přispívaji k utvářeni vědomí člověka socialistické společnosti; odborná činnost muzeí a galerií musí jednoznačně vyústit v živou kulturně výchovnou činnost; muzea a galerie se musí podílet na úsilí celé naši společnosti - vrátit lidem viru v socialistické hodnoty, podporovat $v$ nich presvědčení, že jsou s to porozumět skutečným kulturním hodnotám. "9
„Zásady“ byly vypracovány Ústředním muzeologickým kabinetem, který byl jedním z pracovišt' Národního muzea. Vznikl př́ejmenováním v roce 1973 poté, co byly přijaty „Zásady“, a Ústřední muzeologický kabinet se stal součástí sítě ústředních muzeí. Kabinet řešil zejména problémy péče o muzejní sbírky, ale také „,politickou“ výchovu a odborný růst pracovníků muzeí. Stál za všemi zásadními normami, které se v období 70. a 80. let minulého století dotýkaly českého muzejnictví. Šlo zejména o „Zásady“ a pak také o dokumentaci soudobé společnosti. ${ }^{10}$

Ústř̌ední muzeologický kabinet stál rovněž za metodikou, která definovala dokumentaci současnosti a určovala, co mají muzea sbírat a jak mají mapovat zejména období po roce 1948. A rovněž definoval podobu stálých expozic dějin 20. století a výstav věnovaným událostem posledního století. ,Je proto prvořadým úkolem rozpracovat urychleně teoretické problémy dokumentace současnosti muzejními formami i jejich praktickou aplikaci tak, aby mohl být v muzeích všestranně doložen vybranými sbirkovými predměty přechod od kapitalismu $k$ socialismu i rozvojové proměny československé společnosti. ... Hlavním ideově politickým úkolem muzei je proto dobudování historických expozic až do současnosti, a to především v Národním muzeu, Moravském muzeu a dále pak ve významných muzeích regionálních tak, aby v nich návštěvníci mohli sledovat vývoj společnosti $i$ ve 20. století, se zvláštním dirrazem na obdobi socialistické výstavby jakožto vyvrcholení celého boje o beztřídní společnost. "11 Aby tyto úkoly mohla muzea plnit, vznikala v ústřredních muzeích oddělení novodobých českých dějin. Oddělení novodobých českých dějin v Národním muzeu vzniklo v roce 1973. Ovšem zpočátku bylo vedeno jako nesbírkové oddělení. Mělo shromažd’ovat informace o sbírkách věnovaných dějinám 20. století, které byly uloženy v jiných institucích. Měl zde být vybudován i fotoarchiv, doplněný kartotékou ikonografie moderních českých dějin. Vzhledem k tomu, že se ukázala nutnost realizovat vlastní výstavy z dějin 20. století, začalo oddělení v roce 1977 přijímat první sbírkové předměty. Od počátku se akviziční činnost zaměřovala na dějiny každodennosti a politický život, čemuž odpovídá i struktura akvizic oddělení. Oddělení se sbírkově zaměřovalo na oblast vybavení domácnosti, sériovou textilní výrobu, obchod, reklamu, fotografickou dokumentaci volného času apod. Samozřjejmě se nevyhnulo ani dokumentaci politických událostí, ovšem specializovalo se na akvizici předmětů spojených s významnými událostmi a osobnostmi dějin 20. století. Tímto svým zaměřením se oddělení snažilo vyčlenit vůči stranickým muzeím. ${ }^{12}$

Výstavy byly obecně považovány za důležitou součást činnosti oddělení. „,Nejpřrirozenějším projevem práce muzea pro veřejnost je expozice nebo přiležitostná výstava. Je to

\footnotetext{
${ }^{5}$ Poučení z krizového vývoje ve straně a společnosti po XIII. sjezdu KSČ, Praha 1970, s. 1.

${ }^{6}$ Zásady rozvoje českého muzejnictví, Muzejní a vlastivědná práce, 1973, roč. XI (81), č. 4, s. 221.

Důvodová zpráva k Zásadám rozvoje českého muzejnictví, Muzejní a vlastivědná práce, 1973, roč. XI (81), č. 4, s. 216.

8 Di̊vodová zpráva, s. 217.

9 Dưvodová zpráva, s. 219. Další principy byly věnovány akviziční činnosti, stratifikaci muzeí, personální otázce, ekonomické činnosti a rrízení ze strany centrálních orgánů.

${ }^{10}$ Pavel DOUŠA, Organizace českého muzejnictví 1975-1989, Dizertační práce, Slezská univerzita v Opavě, Filozoficko-př́rodovědecká fakulta, Opava 2005, s. 165-166.

${ }^{11}$ Muzeologické sešity, č. 5, 1974, s. 4, 12.

${ }^{12}$ Podobně např. oddělení nových dějin Moravského zemského muzea, které rovněž vzniklo v roce 1973, se zaměřilo na dokumentaci období první světové války. Bližze viz Zdeněk VARDAN, Přispěvek k historii oddělení nových dějin Moravského muzea, in: Ad musealem laborem. Sborník k pětašedesátinám PhDr. Slavomíra Brodessera, Moravské zemské muzeum, Brno 2005, s. 145.
} 
samozřejmě i projev nejpůsobivější. "13 Dílčí výstavy byly vnímány jako důležitá př́ípravná fáze ve tvorbě stálé expozice, $\mathrm{k}$ jejímuž otevření vše směřovalo a která měla být vyvrcholením výstavní činnosti oddělení. Otevřena byla v roce $1986 .{ }^{14}$ Podobu stálé expozice definovaly i Pokyny pro tvorbu expozic období výstavby socialismu $v$ muzeich (dále „Pokyny“), které vydalo ministerstvo kultury v roce 1976. Pro Národní muzeum to v podstatě znamenalo dokončit stálé historické expozice, protože stávající končily obdobím raného středověku a centrální historická expozice zde úplně chyběla. Pokyny určovaly, jak má být v expozicích (a přeneseně i v krátkodobých výstavách) interpretována minulost. V úvodu „Pokynů“ bylo konstatováno, že budování expozic období výstavby socialismu ,je současným hlavním ideově politickým a kulturně výchovným úkolem muzeí, vyplývajícím ze zájmů naši socialistické společnosti a potřeb jejího kulturního rozvoje ". ${ }^{15}$ Bylo vyzvednuto zejména jejich působení a vliv na mládež. Současně ale byl kladen důraz na estetickou funkci, mezioborovost a použití moderních výstavních prostředků a originálních sbírkových předmětů. Expozice budování socialismu měla být vygradováním historických expozic. Jejich realizace se neměla omezit pouze na centrální muzea, ale v podstatě byla nařízena v městských, okresních, krajských a specializovaných muzeích. Expozice pak byly doprovázeny výstavami, které reflektovaly důležité události z dějin 20. století, jež utvrzovaly požadovaný výklad dějin. ${ }^{16}$ Vzhledem $\mathrm{k}$ tomu, že expozice dějin 20. století byla otevřena až v roce 1986, k interpretaci dějin 20. století sloužily krátkodobé výstavy.

Výstavy Národního muzea v období takzvané normalizace nevybočovaly z naznačeného schématu. Pravidelně se objevovaly výstavy k výročí Velké ř́ijnové socialistické revoluce, Mnichova, konce 2. světové války, února 1948, založení KSČ, IX. sjezdu KSČ, mostecké stávce anebo k výročí SNP. Tedy výstavy o tématech a historických událostech, které tvořily základ revoluční linie československých dějin 20 století. A které plně odpovídaly konceptu dějin definovanému v Poučení z krizového vývoje. Měly různé náměty a pojetí, ale vždy sloužily k podpoře režimu a měly vyzvednout zásadní roli KSČ v popisovaných událostech a úspěch komunistického režimu v Československu. Výstavy byly realizovány v prostoru Hlavní budovy Národního muzea (zejména $\mathrm{v}$ př́zzemních výstavních prostorách v tzv. Hollareu) a také ve vestibulu metra. Tento prostor byl považován za zásadní v tom, jak ideově a výchovně ovlivnit desítky tisíc lidí tímto prostorem procházející.

Velmi často se $\mathrm{v}$ úvodu libret a scénářu autoři výstav vymezovali vůči stranickým muzeím, zejména vůči Muzeu Klementa Gottwalda. Odkazovali se na jeho výstavy a stálou expozici a argumentovali, že se musí od jejich výstav odlišovat. Hlavní distinktivní prvek viděli v tom, že se v rámci svých výstav zaměřovali hodně na každodenní život a na

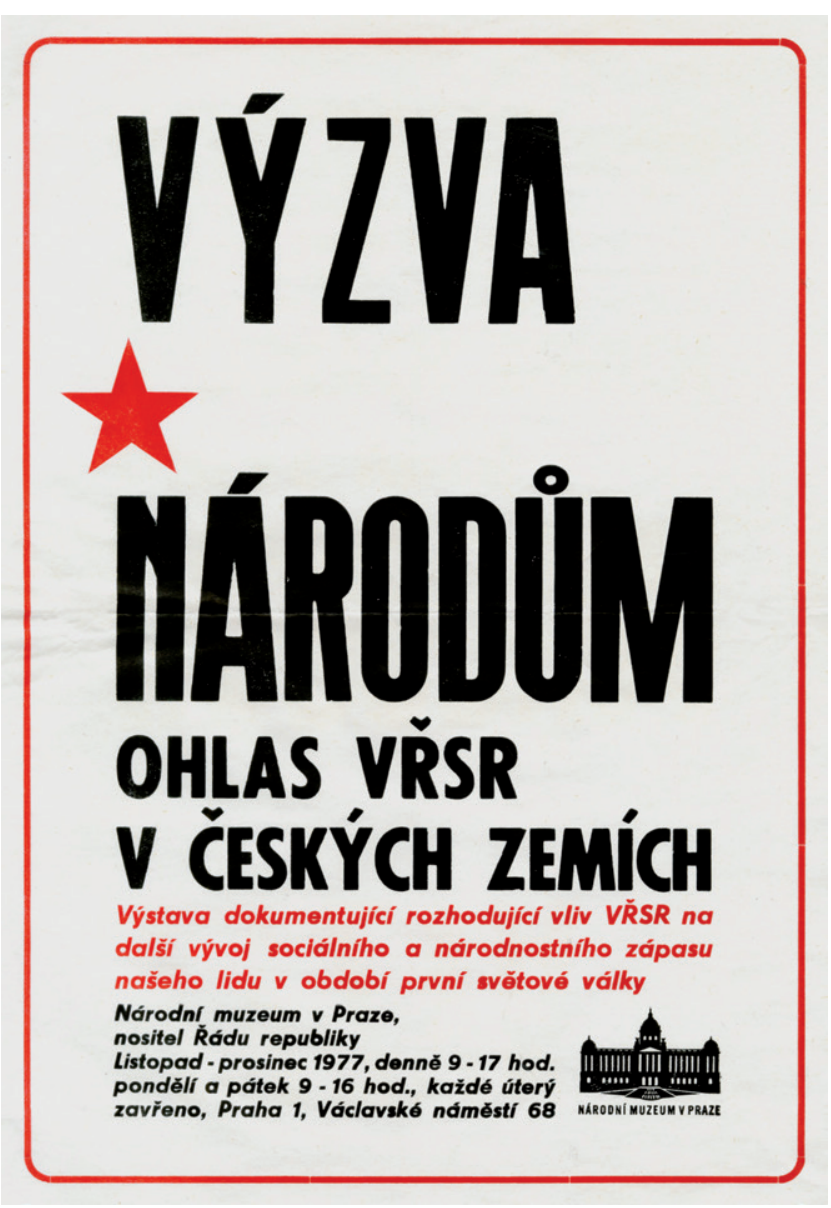

Obr. 1. Plakát výstavy Výzva národům k výročí Velké řijnové socialistické revoluce, 1977, Národní muzeum.

snahu členit popisované události do reálných historických souvislostí. Ale samozrrejmě události byly vždy vybírány tak, aby se popisovaný jev jevil jako „nezbytné vyústění situace ve společnosti“ a dokázal správnost cesty vedoucí k vybudování socialistické společnosti ${ }^{17}$. Základem popisovaných událostí ve scénářích bylo vylíčení třídního boje jako hlavního principu dějin 20. století. Obraz společnosti byl omezen na dělnickou třídu a politiku KSČ. Při charakteristice výstav se autoři nevyhýbali ani vnímání výstav v Národním muzeu jako výstav agitačních a „nastavujících zrcadlo“. Pozitivním prvkem byl fakt, že autoři se vždy snažili klást důraz na prezentaci trojrozměrných předmětů spojených s dějinami. I když ne vždy se jim to povedlo. A velmi často výstavy reflektující dějiny 20 . století byly velmi úzce propojeny s odbornou aktivitou jednotlivých pracovišst'. Ukazovaly roli Národního muzea v rámci dokumentace soudobé společnosti a prezentovaly sbírkotvornou politiku Národního muzea. Toto pojetí můžeme vnímat jako určitý způsob úniku, jak se odchýlit od prŕlišné ideologizace výstav.

\footnotetext{
${ }^{13}$ Národní muzeum, Archiv oddělení novodobých českých dějin, karton 4, Kultura lidu. Propagační výstava Národního muzea v Praze ke 35. výročí Vítězného února, s. 1.

${ }^{14}$ Marek JUNEK, Expozice novodobých českých dějin v Národním muzeu, Časopis Národního muzea. Řada historická, 2016, roč. 185, č. 3-4, s. $49-58$.

${ }^{15}$ Pokyny pro tvorbu expozic období výstavby socialismu v muzeích, in: Informace 1978-2, Ústřední muzeologický kabinet: Národní muzeum v Praze 1978 , s. 8.

${ }^{16}$ Pokyny pro tvorbu expozic, s. 8-9.

${ }^{17}$ Národní muzeum, Archiv oddělení novodobých českých dějin, karton 3, dopis adresovaný řediteli Knihovny Národního muzea dr. Vrchotkovi jako reakce na jeho kritiku Ideového záměru výstavy k 60. výročí KSČ, 20. srpna 1980.
} 
Vzhledem k tomu že se výstavy k výročí neustále opakovaly, bylo velmi komplikované je tematicky konstruovat tak, aby se od sebe lišily. Asi nejvíce se to povedlo u výstav připomínajících kulatá a půlkulatá výročí konce druhé světové války. Kromě klasických výstav věnovaných pražskému povstání a roli Rudé armády při osvobozování Československa (o americké se samozřejmě nemluvilo) vzniklo několik projektů pojatých komplexněji. V roce 1975 byla výstava k výročí roku 1945 věnována ekonomice těsně po skončení války a zejména proměně vlastnické struktury československé hospodářství a změně životního stylu obyvatel Československa.

V roce 1980 vznikla výstava s názvem Novou cestou. Byla realizována u př́ležitosti 35 výročí osvobození Československa rudou armádou. Vnímala konec války jako počátek cesty vedoucí k socialistické společnosti. Poslední výroční válečná výstava v roce 1985 pak byla fotografická a věnovala se období 1938 až 1939.

Pravidelně se také opakovaly výstavy připomínající únor 1948 a IX. sjezd KSČ. Koncept těchto výstav byl totožný. Vycházely z teze, že IX. sjezd KSČ vytyčil úkol vybudovat socialismus v Československu. A tento cíl z mnoha různých pohledů odrážely i výstavy Národního muzea, jednou se věnovaly průmyslu, jindy kultuře. Nejvýznamnější byla výstava z roku 1979 s názvem Kultura lidu a pro lid.

Národní muzeum také často prezentovalo svoje dějiny a sbírky. Vedle výstavy věnující se naprríklad 150 letům vydávání Časopisu Národního muzea to byly výstavy, které zachycovaly dějiny Národního muzea ve druhé polovině 20 století. Naprosto zásadní výstavou zachycující vývoj Národního muzea se stal projekt s názvem 35 let práce Národního muzea, který zachycoval jeho dějiny v letech 1948 až 1983.

Poslední dvě výstavy před pádem komunismu v Československu se od sebe nemohly více lišit. První připomínala 40. výročí „Vítězného“ února a byla plná ideologických klišé. Druhá výstava pak byla výrazně zajímavější. Projekt byl připravený do Vídně, zachycoval vznik Československa $\mathrm{v}$ roce 1918 a zachycoval dějiny oproštěné od ideologie.

$\mathrm{V}$ rámci výzkumu byl prostudován archiv novodobých českých dějin věnovaný výstavní činnosti. Bylo vybráno sedm výstav, vyřazeny byly některé drobné výstavy, které byly určeny např̀. pro menší muzea a kulturní domy. Práce vychází z uložených scénářů, případně posudků a tiskových oznámení o jednotlivých výstavách.

\section{Cestou k socialistickému hospodaření, 1975}

Jedna z prvních větších výstav oddělení novodobých českých dějin po jeho obnovení v roce 1973 byla věnována ekonomickému vývoji v Československu po roce 1945. Byla součástí výstav, které reflektovaly 30 . výročí od konce 2. světové války. A také navazovala na předchozí výstavy Národního muzea, které se věnovaly období let 1939-1945. „Výstava pripomene predevším mnohotvárnost začínajících změn ve vlastnické struktuře hospodářství. Musí také připomenout složité tř́dní a politické pozadí všech změn, zakryté

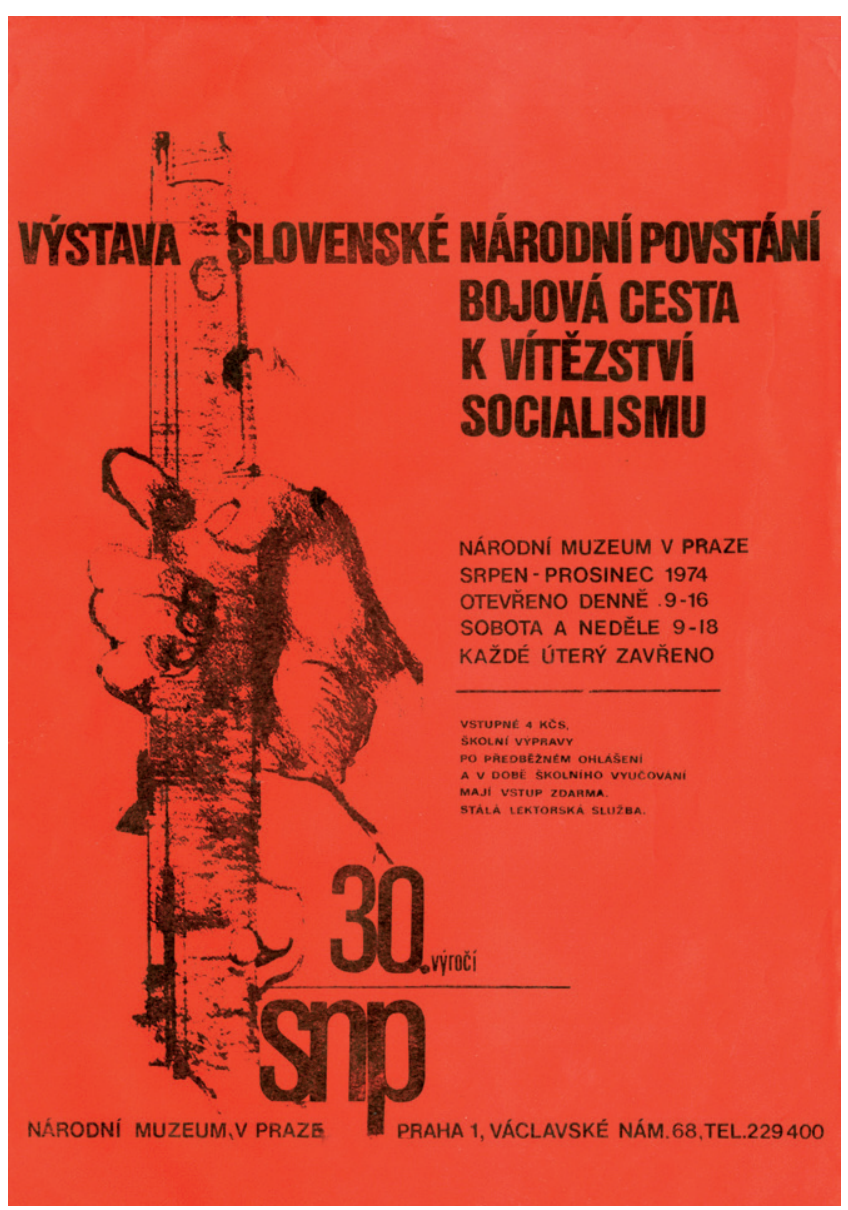

Obr. 2. Plakát výstavy k 30. výročí Slovenského národního povstání, 1974, Národní muzeum.

sice v této době ještě vlnou vlasteneckého nadšení, ale jen proto zdánlivě neprritomné. Chce se pokusit připomenout i počinající proměny v myšlení lidí, snahu vedoucich orgánů pokrokových společenských organizací o transformaci národního enthusiasmu v trvalý, uvědomělý vztah člověka ke společnému majetku. "18 Svým zaměřením na vývoj ekonomiky se autoři snažili vyhnout politickým dějinám, ovšem v okamžiku, kdy ekonomiku začlenili do širšího vývoje, politický vývoj museli reflektovat. Výstava byla zaměřena zejména na mladou generaci a obsahovala celou řadu didaktických prvků.

Výstava neměla poskytnout komplexní obraz, ale vzhledem $\mathrm{k}$ malému prostoru byla zvolena forma průhledů do minulosti v podobě stručného deníkového záznamu. Protože byly využity zejména archiválie, autoři při zpracování kladli důraz na výtvarnou stránku výstavy. Celkem bylo prezentováno 10 témat pokrývajících zejména události roku 1945 . $^{19}$

Úvodní panel vysvětlil nevyhnutelnost změn směřujících ke znárodnění a k podpoře obyvateli Československa. Důraz byl kladen na osudy obyčejných lidí, kteří museli čelit komplikovaným poválečným sociálním a ekonomickým problémům, dále byla ukázána debata o znárodnění, proměny venkova, dobrovolné zapojení obyvatel do obnovení průmyslu. Výstava vyvrcholila ř́jnovými dekrety,

\footnotetext{
${ }^{18}$ Národní muzeum, Archiv oddělení novodobých českých dějin, karton 1, Stanislav SLAVÍK, Cestou k socialistickému hospodaření. Scénář výstavy věnované vzpomínce na prvý rok hospodaření osvobozeného Československa, s. 1-2.

${ }^{19}$ Tamtéž, s. 2-4.
} 


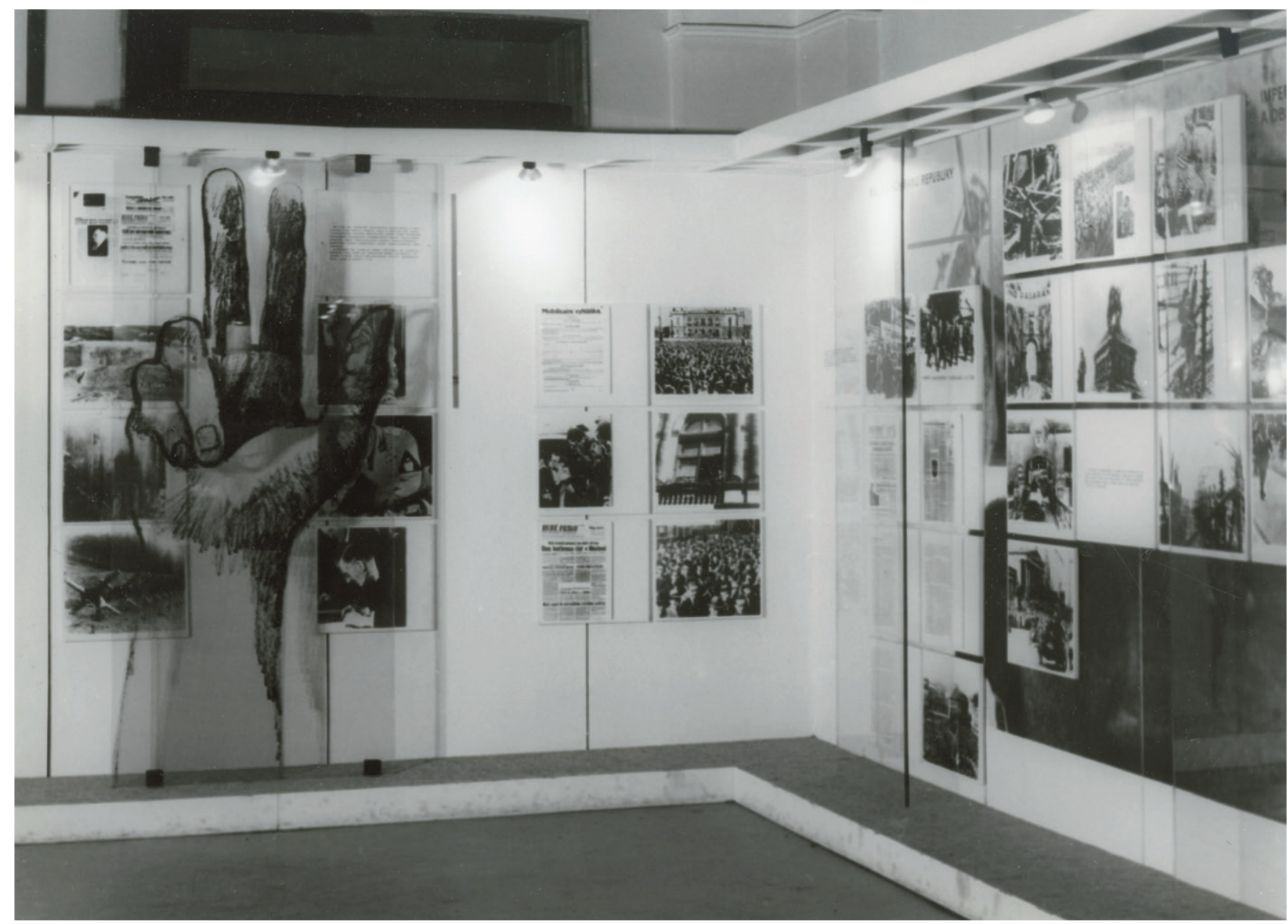

Obr. 3. Pohled do výstavy Slovenské národní povstání, 1974, Národní muzeum.

které znárodňovaly klíčový průmysl, a také zájmem obyvatel ČSR. ${ }^{20}$,,V podzimnich mésících se národohospodářská problematika stala každodenním tématem novinářských úvah a předmétem hlubokého zájmu nejširšich vrstev obyvatelstva. Bezprostřední následky války zvolna zanikaly a lidé upínali pozornost $k$ budoucnosti. "21 Výstava tak ukazovala nezbytnost změn v oblasti průmyslu a interpretovala je jako jedinou správnou cestu.

Výstava ukazuje základní problém výstav oddělení novodobých českých dějin věnovaných 20 . století. Tím byl nedostatek předmětů, které by bylo možné vystavit. Výstava Cestou k socialistickému hospodaření byla založena pouze na fotografiích, novinách a dokumentech, ovšem naprosto chyběly trojrozměrné předměty. Bylo to dáno krátkým časovým obdobím, které uplynulo od vzniku oddělení, ale také tím, že výstavy k výročím neodpovídaly sbírkotvorné koncepci oddělení a jednotliví autoři výstav si museli vypomáhat pomocným materiálem, který se stal hlavní náplní výstavy a klíčovým vyjadřovacím prostředkem.

\section{Kultura lidu a pro lid, výstava konaná k výročí IX. sjezdu KSČ, 1979}

Výstava mapovala všestranný rozvoj kultury v Československu po roce 1949 a hlavní rysy kulturní politiky mezi IX. a XV. sjezdem KSČ. Výstava vrcholila současnou kulturou. Jejím hlavním smyslem bylo dokumentování profesionální umělecké tvorby, bohaté lidové kultury a následně vytvoření obrazu kultury, ze které každý obyvatel ČSSR může čerpat a který ho formuje. Hlavním smyslem bylo tedy ukázat úspěšnost kulturní revoluce a zmasovění kultury v komunistickém Československu. „,Prudký rozmach kultury a uměni se reflexivně prolíná zpět do života pracujících ve vzestupné tendenci kulturního vědomí národa a jeho vztahu $k$ socialistickému umění a socialistické kultuře vübec. "22 Výstava byla členěna do 16 částí, které reflektovaly kulturní politiku strany v letech 1949-1979, což byl středobod celé výstavy. Výstava dále prezentovala významná umělecká díla a jednotlivé oblasti kultury a kulturu ve vztahu k zahraničí. Vyvrcholením výstavy pak byl citát G. Husáka o významném podílu socialistického umění na formování socialistického člověka. ${ }^{23}$

\footnotetext{
${ }^{20}$ Tamtéž, s. 5-20.

${ }^{21}$ Tamtéž, s. 18.

${ }^{22}$ Národní muzeum, Archiv oddělení novodobých českých dějin, karton 7, Kultura lidu a pro lid. Scénář výstavy k výročí IX. sjezdu KSČ, s. I-1.

${ }^{23}$ Tamtéž, s. I-2, I-4.
} 
Předmětově byla úvodní část výstavy tvořena zejména dokumenty dokládajícími základní politiku strany (zákony, rukopisy projevů K. Gottwalda ad.). Naprosto byl opomenut kulturní vývoj ve druhé polovině 60 . let, v textech se zmiňovaly pouze boje ,,strany s oportunistickými myšlenkami v oblasti kultury“. ${ }^{24}$ Podobně byl vystaven text „Anticharty“, ale nikde nebyla zmínka o prohlášení Charty $77 .{ }^{25}$ $\mathrm{V}$ rámci prezentace umění byl kladen důraz na literaturu a výtvarné umění a plastiku. Asi nejvíce inspirativní částí pak byla pasáž, která se zabývala strukturou kultury (kina, divadla, galerie, tiskárny, nakladatelství) v Československu a prezentací nejvýznamnějších kulturních podniků. Její součástí byla i památková péče a řemeslná výroba. Speciální místo bylo věnováno i hudbě. ${ }^{26}$ Výstava tak poskytla plastický obraz oficiální kultury v širokém slova smyslu. O samizdatové, respektive exilové literatuře, o tom, že část umělecké scény stojí mimo oficiální kulturu, si návštěvníci mohli udělat pouze představu $\mathrm{z}$ dokumentů, které na ni reagovaly, ale nespecifikovaly ji.

\section{0. výročí vzniku KSČ, 1981}

Další výstava, která reflektovala významné výročí v novodobých dějinách Československa. Podle autorů neměla podávat komplexní obraz vzniku KSČ. Autoři se rozhodli nevěnovat pouze samotnému aktu založení KSČ, ale celkové společenské situaci. „Za adekvátní přistup k danému úkolu považuji autoři ideového záměru využití metody postupného vytvárení obrazu životního způsobu a politických postojů tehdejši společnosti, předevšim dělnické tř́dy, jejiž nejlepši predstavitelé stáli u založení komunistické strany. "27 Výstava se konala $\mathrm{v}$ prostorách podchodu u Národního muzea, který byl považován za velmi důležitý, protože jím denně prošly tisíce lidí a bylo tak na ně možné výchovně a ideově působit. Proto pracovníci novodobých dějin kladli důraz na výtvarnou a grafickou stránku výstavy, která měla přitáhnout pozornost návštěvníků a současně adekvátně vyjádřit myšlenku výstavy. To vnímali jako problém a poukazovali na dosavadní negativní zkušenost s grafiky, kteří byli vybráni, aniž by předtím realizovali výstavní projekt. ${ }^{28}$ Zajímavý je rovněž fakt, že při obhajobě výstavy (kritické poznámky autorům poslal dr. Vrchotka - tehdejší ředitel Knihovny Národního muzea) pracovníci novodobých dějin argumentovali tím, že chtějí prezentovat jiný koncept, než je běžný v Muzeu Klementa Gottwalda, a chtějí téma vzniku KSČ prezentovat v dobovém kontextu. ${ }^{29}$ Dobový kontext byl ale podmíněn oficiálním pohledem na vznik Československa v roce 1918 a tezí o tř́íním boji v období 1. ČSR

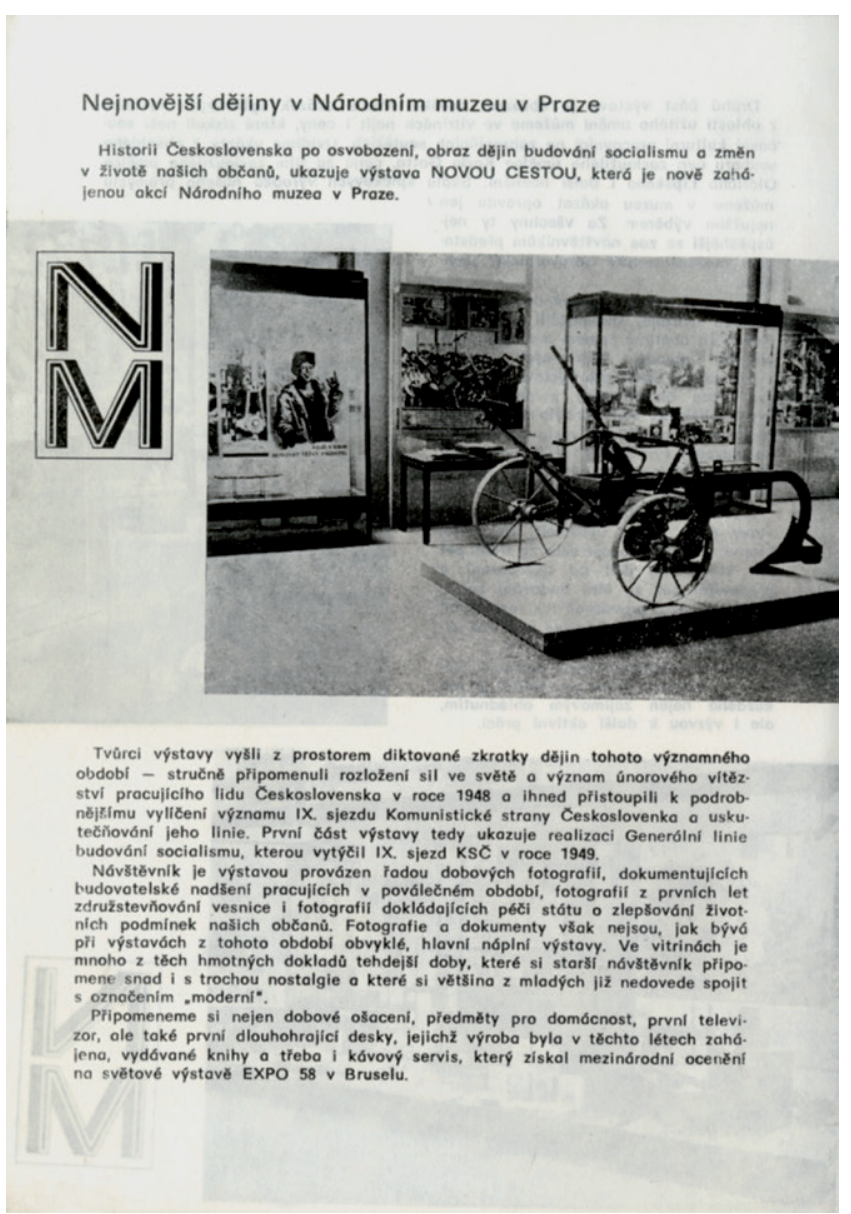

Obr. 4. Propagační leták k výstavě Novou cestou, 1980, Národní muzeum.

\section{Kultura lidu, 1983}

Výstava k 35. výročí únorového převratu byla opět realizována $\mathrm{v}$ podchodu metra u Národního muzea. Výstava neměla reflektovat historické události, ale měla ukázat, že „Vítězný únor" nastartoval změny v kultuře a v kulturní politice státu. Původně výstava měla zobrazit péči státu o kulturní památky, nakonec byl námět výstavy ,transformován do podoby zprávy o práci muzea a o predpokladech této práce, o některých zásadách kulturní politiky socialistického Československa, jak jsou obsaženy v zákonné normě “. ${ }^{30}$ Důvod byl ten, že podobně jako v prípadě jiných výstavních projektů bylo na samotnou prípravu výstavy vyhrazeno jen velmi málo času. Zjednodušeně řečeno, výstava se dotýkala Národního muzea jako pamět’ové instituce, která uchovává odkaz předků, kontinuitu vědomostí o minulosti a při jejich uchovávání používá vědecké metody. ${ }^{31}$ A tato funkce muzea měla být v přitažlivé podobě přiblížena veřejnosti.

\footnotetext{
${ }^{24}$ Tamtéž, s. II-4.

${ }^{25}$ Tamtéž, s. II-7.

${ }^{26}$ Tamtéž, s. II-10-II-20.

${ }^{27}$ Národní muzeum, Archiv oddělení novodobých českých dějin, karton 3, Ideový záměr výstavy k 60. výročí KSČ, 1980.

${ }^{28}$ Tamtéž. Autoři také argumentovali tím, že mají zkušenosti s prípravou výstav do podchodu, protože v minulých letech připravili výstavy Volby a lidé, Proměny světa nebo Mostečtí havírii.

${ }^{29}$ Národní muzeum, Archiv oddělení novodobých českých dějin, karton 3, dokument Výstava k 60. výročí vzniku KSČ, 20. srpna 1980.

${ }^{30}$ Národní muzeum, Archiv oddělení novodobých českých dějin, karton 4, Kultura lidu. Propagační výstava Národního muzea v Praze ke 35 . výročí Vítězného února, s. 2.

${ }^{31}$ Tamtéž, s. 13.
} 
Výstava prezentovala práci Př́rodovědného a Historického muzea, Náprstkova muzea, Národopisného muzea, Českého muzea hudby a Knihovny Národního muzea. Princip výstavy byl podobný jako $\mathrm{v}$ předchozích případech důraz byl kladen na grafické vyznění výstavy, vypovídající fotografie a sbírkové předměty. Text byl vždy jeden hlavní $\mathrm{k}$ tématu, $\mathrm{k}$ němu byly doplněny texty komentáře tvořené citáty zákonných norem a popisky $\mathrm{k}$ exponátům. ${ }^{32}$ Důležitou součástí scénáře je i úvaha o tom, jak vůbec s podchodem metra pracovat. Pracovníci oddělení novodobých českých dějin si uvědomovali, že to není „klasický“ výstavní prostor, kde je možné vyprávět ucelený příběh. Proto vytvořili jednotlivé dílčí obrazy, které vždy zahrnovaly 2-3 vitríny zobrazující jedno téma - činnost jedné odborné složky Národního muzea. ${ }^{33}$

\section{Dějiny v obrazech, 1985}

Výstava ukazovala dějiny Československa v letech 19381945. Představila zejména roli KSČ při vedení domácího odboje (její význam byl naprosto zveličený) a význam SSSR. Ostatní součásti odboje byly potlačeny, umenšen byl i význam atentátu na Heydricha. Rovněž tak byl naprosto marginalizován západní odboj, role Československých letců v RAF apod. ${ }^{34}$ Př́běh byl konstruován tak, aby z něj jednoznačně vyplynula nezbytnost převzetí moci v Československu KSČ v roce 1948. „Komunisté prokázali, že mají právo, že maji dějinnou nutností povinnost stát se vedoucí složkou společnosti prebudované jejich zásluhou ve společnost spravedlivě rízenou, společnost socialistickou. " 35

\section{První desetiletí socialistického Československa, 1988}

Výstava byla věnována 40. výročí 25. února 1948. Konala se v okamžiku, kdy již byla v Hlavní budově Národního muzea otevřena stálá expozice věnovaná dějinám 20. století, kterou připravilo oddělení novodobých českých dějin. ${ }^{36}$ Výstava proto byla umístěna v předsálí stálé expozice. Zaměřila se na období let 1948-1958, tedy na dobu, kdy byl v Československu budován socialismus. Důraz byl kladen na kulturu, ekonomiku a proměnu krajiny. ${ }^{37}$ Výstava se tak opět snažila vymezit vůči výstavám stranických muzeí a klást důraz na zobrazení každodennosti. Výstava ale byla inovativní v tom, že ,,z hlediska muzea a potřeb muzejní práce chce upozornit na aktuálni potřebu uchováni památek z tohoto období. ... Proto připomenutím dnešního profilu muzejnich sbirek chceme veřejnost upozornit na skutečnost, že právě zde by měla muzeu prispět svoji prací, aby nezanikla pamét' a odkaz doby, kterou starši a středni generace ještě pocitově nevnímá jako ,skutečnou' historii. "38 Proto byl ve výstavě kladen důraz na prezentaci sbírkových předmětů a dle autorů byl potlačen význam fotografií (zejména velkoformátových) a archivních materiálů, které ve výstavách oddělení novodobých českých dějin do té doby hrála často dominantní roli. A také se kladl důraz na práci muzea právě v období let 1948-1989. ${ }^{39}$ Výstava tedy měla sloužit jako vzkaz veřejnosti, aby do muzea darovali předměty spojené s obdobím po roce 1948. Výstava se tak stala jedním z bodů naplňování soudobé dokumentace, které pro oddělení novodobých českých dějin byla jedním z hlavních bodů jeho činnosti.

Tematicky byla výstava členěna na několik celků: vydavatelská politika a knižní kultura, divadlo, hudba, lidové umění, sport, proměna krajiny. Na jednotlivá témata navazovala prezentace plakátů a modelů, které následně přešly do stálé expozice. ${ }^{40}$ Politický rámec výstavy pak tvořil únorový převrat a IX. sjezd KSČ. Texty byly řešeny podobně jako v předchozích výstavách - dominantní texty doplňovaly komentáře, které charakterizovaly ,jak se tyto ,nové momenty společenského děni ' promitaly do činnosti složek a oddělení muzea". ${ }^{41}$

Přestože v úvodní části autoři deklarovali, že výstava bude založena na prezentaci trojrozměrných předmětů, realita byla odlišná. Ukázalo se to zejména v politické části, kde exponáty v podstatě chyběly a nahrazovaly je právě archiválie a fotografie doplněné odznaky.

\section{Samostatnost Československa, 1988 (výstava konaná ve Vídni)}

Výstava měla v dramaturgii výstav oddělení novodobých českých dějin specifické místo. Věnovala se vzniku Československa v roce 1918 a byla připravena pro rakouské publikum. Vznikla ve spolupráci s Československou společností pro mezinárodní styky a měla se stát základem pro další působení československých muzeí v Rakousku. Autor scénáře si byl vědomý, že jde i po 70 letech o citlivé téma, a proto v rámci výstavy nechtěli poučovat, ale snažili se představit současné pojetí výkladu těchto událostí, tzn. že chtěli představit marxistické pojetí výkladu vzniku Československé republiky. ${ }^{42}$ Výstava se skládala ze tř́ základních částí: událostí 1. světové války, vzniku Československa včetně vlivu událostí v Rusku na radikalizaci situace v Československu a dokladů vývoje československé státnosti. Pozitivní byl fakt, že výstava měla především reflektovat dobovou atmosféru a konkrétní muzejní sbírky. ${ }^{43}$

Ve své podstatě se jednalo o panelovou výstavu doplněnou několika málo předměty, prapory, oděvy a plastikami. Samotné texty byly obsáhlejší, byly členěny na dvě

\footnotetext{
32 Tamtéž, s. 3-4.

33 Tamtéž, s. 4.

${ }^{34}$ Národní muzeum, Archiv oddělení novodobých českých dějin, karton 3, Dějiny v obrazech.

35 Tamtéž, s. XXX/a.

${ }^{36}$ Viz M. JUNEK, Expozice novodobých českých dějin v Národním muzeu, s. 49-58.

${ }^{37}$ Národní muzeum, Archiv oddělení novodobých českých dějin, karton 2, První desetiletí socialistického Československa, s. 3-4.

38 Tamtéž, s. 4.

39 Tamtéž, s. 7.

40 Tamtéž, s. 5-6.

41 Tamtéž, s. 7.

${ }^{42}$ Národní muzeum, Archiv oddělení novodobých českých dějin, karton 1, Stanislav SLAVÍK, Samostatnost Československa, scénář výstavy pro Rakouskou republiku, s. 1-2.

43 Tamtéž, s. 2-3.
} 

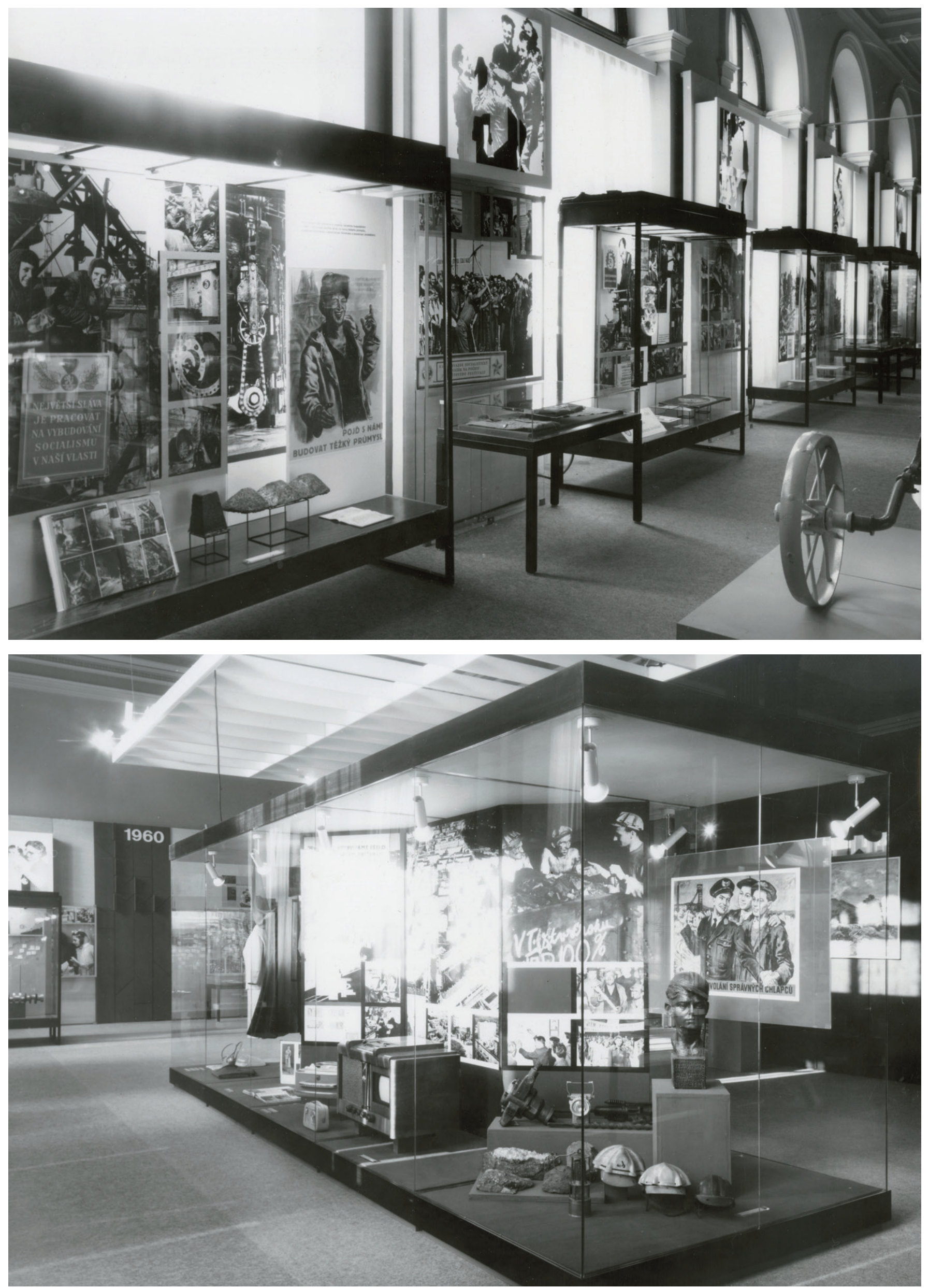

Obr. 5 a 6. Pohled do výstavy Novou cestou, 1985, Národní muzeum. 
části - hlavní text a chronologické glosy. Obsahově je nutno konstatovat vyváženost texti̊. Kromě povinných poznámek o vlivu dění v Rusku na vznik ČSR byly zmíněny i události v souvislosti s činností T. G. Masaryka a zahraničního odboje na západě. Samozřejmě, pokud jde o dění v Rusku, výstava zobrazila vstupy Čechů a Slováků do Rudé armády. ${ }^{44}$ Legie byly zmíněny jen u popisek fotografií, které zachycují T. G. Masaryka v Rusku. ${ }^{45}$ Ve scénáŕi výstavy se projevila interpretace dějin ${ }^{46}$ směřující k objektivnímu zachycení vzniku Československa a podílu zahraničního odboje při jeho vzniku.

\section{Závěr}

Výstavy věnované dějinám 20. století a připravené oddělením novodobých českých dějin zejména připomínaly výročí důležitá pro komunistický výklad dějin. Přestože se autoři snažili věnovat dějinám každodennosti (a tak i definovali z větší části svoji akviziční činnost), nevyhnuli se stereotypnímu popisu dějin vycházejícímu z Poučení z krizového vývoje a ze „Zásad“. V jednotlivých scénárích se téměř u všech výstav objevuje rozpor mezi ideovým záměrem kladoucím důraz na každodennost a konkrétním obsahem výstavy, kde převládá politické pojetí dějin. Pozitivem všech výstav je skutečnost, že autoři kladli důraz na prezentaci Národního muzea, jeho akviziční a odborné činnosti. Měla ukázat význam a roli Národního muzea ve společnosti. Přestože v Národním muzeu vznikaly i výstavy s tematikou dějin 20 . století a byly výrazně méně ideologicky zatížené, napřs. Stará dělnická Praha a další etnografické a sportovní výstavy, oddělení novodobých dějin se na nich podílelo jen neprrímo. Všechny výstavy, které vznikly v období 70 . a 80 . let 20 . století, se pak do určité míry odrazily ve stálé expozici. Tvořily př́ípravnou fázi, v níž si pracovníci novodobých dějin vyzkoušeli různé postupy a metody práce, jež ve stálé expozici uplatnili. Základní problém všech výstav, které v tomto období byly zrealizovány, se ukázal v nedostatku sbírkových předmětů. Přestože ve všech scénárích bylo deklarováno, že výstavy budou předmětové, realita byla odlišná. Výjimkou byly výstavy, které představovaly vývoj Národního muzea a akvizice po roce 1945 . Zde byly prezentovány předměty, které se prrímo nevztahovaly k 20. století, ale ukazovaly vývoj Národního muzea po roce 1948.

\footnotetext{
${ }^{44}$ Tamtéž, s. 26

${ }^{45}$ Tamtéž, s. 18

${ }^{46}$ Jan GALANDAUER, Vznik Československé republiky 1918. Programy, projekty, perspektivy, Praha 1988.
} 